PAULIUS V. SUBAČIUS

Vilnius University, Lithuania

\title{
CONCORDAT VERSUS AGREEMENTS: EXPERIENCE OF INTEGRATION CHURCH ACTIVITY INTO THE LITHUANIAN LEGAL SYSTEM
}

Soon after the restoration of Independence in 1990, The Act for the Restitution of the Status of the Catholic Church in Lithuania was adopted, which declared cooperation between the State and the Church on the basis of parity. In the opinion of the episcopate, The Restitution Act was a sufficient basis for the cooperation of the Church and the State, and the laws regulating the activity of societies, education, social care and taxes could be coordinated with this act "without introducing any privileges or discrimination"2. The legal forms by which this definition of relations was implemented gradually changed, but the Church consistently supported the idea that it conveyed - religious believers and their organisations were equal members of society, and special acts were necessary to define only a small group of specific questions.

The victory of ex-communists in the parliamentary elections of 1992 brought a sobering realisation that in the conditions of democracy we would have to deal with politicians who were less

\footnotetext{
${ }^{1}$ Kataliku Bažnyčios padeties Lietuvoje Restitucijos aktas, 12 June 1990, No. I-283, in: Register of Legal Acts, https://www.e-tar.lt

${ }^{2}$ Letter from Lithuanian Bishops' Conference to Lithuanian Parliament of 3 October 1990, in: Curia Archives of the Archdiocese of Vilnius, file No. VII.36 "Juridical acts [1988-]1995".
} 
favourable towards religion and, thus, clear legal mechanisms were necessary. Clause 43 of the Constitution, which was adopted at the same time, also provided that "the status of churches and other religious organisations in the State shall be established by agreement or by law"3. However, there were two circumstances that prevented the urgent advancement of the initiative of negotiations. Firstly, the tension caused by the fiery comments of radical clergymen and secular figures about the backlash of ex-communists had to subside a little. Secondly, all attention, including communication with State institutions, had to be directed to the approaching visit of John Paul II in September 1993. Almost immediately after this visit, the Bishops' Conference invited the Government to start a dialogue to define relations, but the latter was not in a hurry ${ }^{4}$.

The early idea that a concordat between the Holy See and the Republic of Lithuania would allow regulating the status of the Church was determined by the historical tradition and the closest international context. The concordat was signed before the war, on 27 September 1927, and remained in force until the Soviet occupation of 1940. The Parliament's Decision on the Act for the Restitution of the Status of the Catholic Church in the Republic of Lithuania obliged "the State Commission to prepare a draft of the renewal of the concordat", but it was not put into life.

The bishops began to discuss a possibility of the concordat in late $1993^{6}$. According to the testimony of Cardinal Audrys Juozas

${ }^{3}$ Constitution of the Republic of Lithuania (1992-10-25), in: Parliamentary record, 1992-11-01, Nr. 11.

${ }^{4}$ Cf. Statement of the Lithuanian Bishops' Conference, 25 January 1995, in: Curia Archives of the Archdiocese of Vilnius, unnumbered file [Varia. Constitution 1992. Agreements 1993-1999].

${ }^{5}$ Nutarimas dèl Kataliku Bažnyčios padèties Lietuvoje Restitucijos akto, 12 June 1990, No. I-282, in: Register of Legal Acts, https://www.e-tar.lt

${ }^{6}$ Discourse by Apostolic Nuncio Archbishop Justo Mullor García to Lithuanian Bishops' Conference of 16 December 1994, in: Curia Archives of the Archdiocese of Vilnius, unnumbered file "Nunciature 1987-..." 
Bačkis ${ }^{7}$, the preliminary document with the subhead "The scheme of a preliminary draft" ${ }^{\circ}$ was presented by the Nuncio Archbishop Justo Mullor García who resided in Vilnius since January 1992. Quite soon the bishops, already having the first variant of the draft ${ }^{9}$, decided to set up an ecclesiastic consultative committee led by Archbishop Backkis to accelerate the work ${ }^{10}$. From 3 February (the date marked on Draft No. 2 of the concordat) to 31 October 1994, six variants that gained an increasingly wider consensus were prepared ${ }^{11}$. The new drafts of the concordat, which were twice shorter, considerably differed from the pre-war document. However, handwritten notes on their pages reveal that the old document was consulted a great deal during the editing ${ }^{12}$. The points under discussion were compared with analogous agreements of Italy (1984) and Poland and draft agreements that were under preparation in other countries, which were received from the Vatican. At this stage the projects were not coordinated with representatives of the state authorities ${ }^{13}$.

\footnotetext{
${ }^{7}$ January 2014, in: Authors' private archives.

${ }^{8}$ Konkordatas tarp Šventojo Sosto ir Lietuvos: [Project], received in Vilnius Curia on 24 December 1993, in: Curia Archives of the Archdiocese of Vilnius, file No. III.8 "The Concordat with Holy See and Agreements".

${ }^{9}$ Konkordatas tarp Šventojo Sosto ir Lietuvos Respublikos: [Draft version No.1, s. d.], in: Curia Archives of the Archdiocese of Vilnius, unnumbered file ["The Concordat"].

${ }^{10}$ Minutes of Plenary meeting of the Lithuanian Bishops' Conference on 11 January 1994, in: Lithuanian Bishops' Conference Archives, file No. A I-1 “LBC meetings (minutes, invitations, agendas) 1989-1996".

${ }^{11}$ Konkordatas tarp Šventojo Sosto ir Lietuvos Respublikos: Draft version No. 6, 31 October 1994, in: Curia Archives of the Archdiocese of Vilnius, file No. III.8 "The Concordat with Holy See and Agreements".

${ }_{12}$ Konkordatas tarp Šventojo Sosto ir Lietuvos Respublikos: Draft versions No. 2, 4 and 5, 3 February 1994 and 14 April 1994, in: Curia Archives of the Archdiocese of Vilnius, file No. III.8 “The Concordat with Holy See and Agreements".

${ }^{13}$ Cf. Minutes of Plenary meeting of the Lithuanian Bishops' Conference on 17 February 1994, in: Lithuanian Bishops' Conference Archives, file No. A I-1 "LBC meetings (minutes, invitations, agendas) 1989-1996”.
} 
In the middle of October 1994, the Prime Minister Adolfas Šleževičius, having received a list of persons delegated by the Church ${ }^{14}$, established a bilateral working group.

In autumn of the same year, the Nuncio was instructed to gear up for the preparation of several different agreements ${ }^{15}$ - in the future, when the Vatican archives become open, they will probably help reveal the considerations of the Secretariat of State and the fact if the stalled ratification of the concordat in Poland played any role. In general, the majority of the bilateral documents signed on the eve of the $21^{\text {st }}$ century by the Holy See took the form of agreements rather than concordats. The early concordats aimed to put an end to the conflicts between the secular and Church authorities as opposing sides. The Second Vatican Council established the understanding that the Church does not coincide but cooperates with the political community, and each of them is independent in their respective fields ${ }^{16}$. The precondition of the new agreements "is not negative - to avoid conflicts, but positive - to build the conditions for cooperation and to provide the best conditions for individuals to exercise their rights in all fields of private and public life"17.

In the meeting between the Nuncio and the Prime Minister on 21 October 1994, it was decided to set up three government working groups that had to maintain contact with the representatives of the Bishops' Conference ${ }^{18}$. The restitution of property that formerly belonged to the Catholic Church, pastoral work of Catholics serving

${ }^{14}$ Letter from Lithuanian Bishops' Conference to Lithuanian Government of 29 September 1994, No. 30/94, in: Curia Archives of the Archdiocese of Vilnius, file No. VII.36 "Juridical acts [1988-]1995".

${ }^{15}$ Information by Cardinal Audrys Juozas Bačkis, January 2014, in: Authors' private archives.

${ }^{16}$ Gaudium et spes, 76.

${ }^{17}$ V. AlišAusKas, Trys sutartys, in: Naujasis Židinys-Aidai [New Fireplace-Echoes], 2000, No. 7/8, p. 365.

${ }^{18}$ The list of representatives of Lithuanian Bishops' Conference, 11 November 1994, No. 3-91, in: Lithuanian Bishops' Conference Archives, unnumbered file "Varia (Ecclesia Universalis) 1971-1994”. 
in the armed forces and the role of the Church in the field of education was within their competence ${ }^{19}$. Cardinal Bačkis later acknowledged that it was "very difficult to break" the resistance of the heads of the State with Soviet mentality, when the Church offered to prepare agreements and normalise the relations in this way ${ }^{20}$. There was less and less hope to sign the agreements, which the episcopate saw as a single complex.

Soon after the parliamentary elections of 1996, in which the rightwing parties won a majority, the Nuncio met with the Prime Minister Gediminas Vagnorius regarding the renewal of the preparation of agreements.

Having exchanged opinions about the future prospects of the negotiations, both the State and the episcopate experienced a shift in the thinking about their priorities. The agreement on the restitution of property, which once served as the starting point of the negotiations ${ }^{21}$, was completely rejected, and instead, a more general document establishing the legal principles of the relations between the Catholic Church and the State was put under discussion. The statements regarding the restitution of rights included in the former draft agreement on the restitution of property were transferred to the Agreement on Cooperation in Education and Culture, only in a much narrower form, as statements regarding the status of the archives that formerly belonged to the Church and

\footnotetext{
${ }^{19}$ Minutes of Plenary meeting of the Lithuanian Bishops' Conference on 17 November 1994, in: Lithuanian Bishops' Conference Archives, file No. A I-1 "LBC meetings (minutes, invitations, agendas) 1989-1996”.

${ }^{20}$ Interview with Cardinal Audrys Juozas Bačkis on 16 April 2013 for radio program "Kultūra ir religija" [Culture and Religion], in: http://www.mstudija.lt/ laidu_archyvas

${ }^{21}$ Lietuvos Respublikos ir Šventojo Sosto sutartis dèl Katalikų Bažnyčios nuosavybès gražzinimo: [Draft version], s. d. [1995], in: Curia Archives of the Archdiocese of Vilnius, file No. III.7 "Agreement between Government of Lithuania and Holy See on restitution of property of the Catholic Church. Activity of Bilateral mixed commission".
} 
movable and immovable objects of cultural value ${ }^{22}$. The Nuncio wrote a preliminary outline of agreements based on the new conception in January $1997^{23}$, and in March the bishops who discussed it set up a working group for preparing draft agreements ${ }^{24}$. The principles approved by the episcopate sought to coordinate the relations between the Church and the State taking into account the understanding of Church service as a mission, advanced by the Second Vatican Council, to stop seeking privileges and to respect the secular nature of the State established by the Constitution and the freedom of faith applied to different religious denominations. As is evident from the document Suggestions by Archbishop Mullor García ${ }^{25}$ and the titles and structure of later draft agreements, the compilers referred not so much to the former projects, but rather to three agreements between the Holy See and the Republic of Croatia, which came into force in February $1997^{26}$.

In the spring of 1998, a draft of the Agreement between the Holy See and the Republic of Lithuania concerning the pastoral care of Catholics

22 Sutarties tarp Šventojo Sosto ir Lietuvos Respublikos dèl bendradarbiavimo švietimo ir kultūros srityse projektas [Draft version], s. d. [1997], in: Curia Archives of the Archdiocese of Vilnius, file No. III.8 "The Concordat with Holy See and Agreements".

${ }^{23}$ Minutes of Plenary meeting of the Lithuanian Bishops' Conference on 9 January 1997, in: Lithuanian Bishops' Conference Archives, file No. A I-2 “LBC meetings (minutes, invitations, agendas) 1997".

${ }^{24}$ Minutes of Plenary meeting of the Lithuanian Bishops' Conference on 7 March 1997, in: Ibid.

${ }_{25}$ Pasiūlymai dèl projektu susijusiu su sutartimis tarp Šventojo Sosto ir Lietuvos, s. d. [January 1997], in: Curia Archives of the Archdiocese of Vilnius, file No. III.8 "The Concordat with Holy See and Agreements"

${ }^{26}$ Agreement between the Holy See and the Republic of Croatia on legal matters, Agreement between the Holy See and the Republic of Croatia about the religious assistance to Catholic faithful, members of the armed forces and the police of the Republic of Croatia, Agreement between the Holy See and the Republic of Croatia regarding their collaboration in the fields of education and culture [originals in Italian and Croatian], in: http://www.vatican.va/roman_curia/secretariat_state/ index_concordati-accordi_en.htm 
serving in the Army was prepared ${ }^{27}$, to be followed by the draft of the Agreement between the Holy See and the Republic of Lithuania on co-operation in education and culture in summer ${ }^{28}$, and untitled drafts that served as the basis for the Agreement between the Holy See and the Republic of Lithuania concerning the juridical aspects of the relations between the Catholic Church and the State in autumn and winter ${ }^{29}$. In parallel, from October 1999 negotiations for Lithuania's membership in the EU were taking place, which implied that a large amount of national laws had to be harmonised with multilateral acts. Due to this fact, the political elite was inclined to assume the obligations that could not be changed according to the local conjuncture. This global-scale process, along with bilateral agreements signed between the Holy See and other Central European countries (Poland, Croatia and Hungary) due the same decade, undoubtedly created a favourable context. The agreements generalised the State's existing practice with regard to religious communities, more serious conflicts were avoided in the talks of the delegation $s^{30}$. During their meeting with the Prime Minister Andrius Kubilius in April 2000, the bishops requested to speed up the drawing of the agreements ${ }^{31}$, and before long, on May 5, Archbishop Ender and the Minister of Foreign Affairs Saudargas signed them ${ }^{32}$. The agreements were successfully ratified in the Parliament on July 20 of the same year. The current agreements showed the modernisation and openness of both sides, and most importantly, revealed a new relation with citizens and members of the Church community based on

27 Susitarimas tarp Šventojo Sosto ir Lietuvos Respublikos dèl katalikų, tarnaujančiu ginkluotose struktūrose, sielovados: [Draft version], 6 April 1998, in: Curia Archives of the Archdiocese of Vilnius, unnumbered file ["The Concordat"].

${ }^{28}$ Sutartis tarp Šventojo Sosto ir Lietuvos Respublikos dèl bendradarbiavimo švietimo ir kultūros srityse: [Draft version], 22 June 1998 and 3 July 1998, in: Ibid.

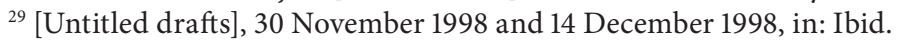

${ }^{30}$ V. Ališauskas, op. cit., p. 366.

${ }^{31}$ [Pro memoria on meeting with Andrius Kubilius], 24 April 2000, in: Curia Archives of the Archdiocese of Vilnius, file No. III.6 "Church and State relations. President Office. Government”.

32 Bažnyčios žinios [Church News], 16 May 2000. 
the primacy of personal freedom. The formulations of the agreements could be understood as helping people to better exercise their rights and fulfil their rightful expectations rather than limiting the powers of secular or Church authorities in any field.

The Agreement concerning the juridical aspects of the relations between the Catholic Church and the State, the clause No. 17 unambiguously obliged: "A Mixed Commission comprised of representatives of both Parties shall be set up for the implementation of the provisions of the present Agreement"33; however, the authorities took their time. At the very end of 2001, the first session of the Bilateral mixed commission finally took place ${ }^{34}$. Suggestions presented by six working groups (in the fields of education, culture, social care, legal regulation, pastoral care in the military and archives ${ }^{35}$ ) were discussed. As pastoral care in the military was already defined in great detail in a separate agreement, and there were quite many examples of other NATO countries, the preparation of the Regulation of the Ordinariate of the Lithuanian Army took place very smoothly ${ }^{36}$, and after less than a year it was adopted ${ }^{37}$. Similarly, an agreement with the Migration Department on the arrival of Church members who were foreign nationals was quickly achieved; the agreement provided for the granting of temporary residence permits on the basis of the Bishop's mediation ${ }^{38}$. The appropriated archives also caused

${ }^{33}$ Valstybès žinios [State News], 9 August 2000, No. 67-2022.

${ }^{34}$ Minutes of the session of the Bilateral mixed commission on 11 December 2001, in: Curia Archives of the Archdiocese of Vilnius, unnumbered file "State".

${ }^{35}$ Premier Minister, Decree "Dèl darbo grupių sudarymo”, 9 August 2001, No. 183, in: Register of Legal Acts, https://www.e-tar.lt

${ }^{36}$ Minutes of the session of the Bilateral mixed commission on 19 February 2002, in: Curia Archives of the Archdiocese of Vilnius, unnumbered file "State".

${ }^{37}$ Lietuvos Vyskupu Konferencijos ir Krašto apsaugos ministerijos susitarimas dèl Lietuvos kariuomenés Ordinariato reglamento, 2 August 2002, No. 140, in: Lithuanian Bishops' Conference Archives, digital collection, unnumbered folder "Church-State covenants".

${ }^{38}$ Lietuvos Vyskupu Konferencijos ir Migracijos departamento prie Lietuvos Respublikos Vidaus reikalų ministerijos susitarimas dèl katalikų Bažnyčios narių užsieniečiu atvykimo i Lietuvos Respublika, 25 July 2002, in: Ibid. 
little discussion, as the Church did not require their physical return, and the representatives of the Government agreed to restrict the use of potentially sensitive documents (personal files of live priests etc.), and after the digitisation of the files return the copies to the former owners.

It took four years to coordinate with the Ministry of Culture the agreement providing for the setting up of the Permanent bilateral commission to solve the issues of cultural heritage ${ }^{39}$. Alongside, the principles that had to build the basis for the law regulating the restitution of movable objects of value to the Church were established ${ }^{40}$. In particular, a lot of specific solutions were needed in the field of education - agreement was sought regarding the publishing of textbooks and teaching aids on religious education, the involvement of specialists in catechetics in a commission of experts in ethics training and the joint certification of teachers of religious education by public education departments and catechetical centres ${ }^{41}$. The complications in making amendments to The Labour Code was the reason why it took ten years to achieve agreement on the procedure of dismissing teachers of religious education who have lost their canonical assignment ${ }^{42}$.

Favourable conditions for pastoral care in prisons had already been created, and in the agreement with the Ministry of Justice, the position of a pastoral care coordinator and the involvement of lay

${ }^{39}$ Lietuvos Respublikos igaliotos institucijos ir Lietuvos Vyskupu Konferencijos susitarimas del Lietuvos Respublikos ir Šventojo Sosto sutarties Dèl bendradarbiavimo švietimo ir kultūros srityje 13 straipsnio 4 dalies igyvendinimo, 2 July 2004, in: Ibid.

40 [Draft of covenant with Ministry of Culture], 2 July 2004, in: Curia Archives of the Archdiocese of Vilnius, unnumbered file [Varia. Constitution 1992. Agreements 1993-1999].

${ }^{41}$ Minutes of the session of the Bilateral mixed commission on 11 December 2001, in: Curia Archives of the Archdiocese of Vilnius, unnumbered file "State".

${ }^{42}$ Lietuvos Vyskupu Konferencijos ir Lietuvos Respublikos Švietimo ir mokslo ministerijos susitarimas dè informavimo apie siuntimo mokyti tikybos netekima, 6 November 2009, in: Lithuanian Bishops' Conference Archives, digital collection, unnumbered folder "Church-State covenants". 
people in the pastoral care of prisoners was legitimised ${ }^{43}$. However, the agreement with the Ministry of Health Care for pastoral care in hospitals was very vague ${ }^{44}$, and it was not until 2009 that the minister finally issued a decree allowing the heads of health care institutions "to establish the position of a chaplain and/or spiritual assistant" 45

The changing understanding of the political elite about the meaning of the Bilateral mixed commission and the level of decision making necessary for its successful work was revealed by the rank of representation. In the first stage of its activity, the chairman of the commission from the side of the State was the Deputy Minister of Culture, from 2003 - the Minister of Culture, from 2007 - the Government Chancellor ${ }^{46}$, and after 2008, the Prime Minister himself sometimes chaired the sessions together with the President of Bishops Conference; finally in 2011, the Government decided that the part of the commission representing the State would be chaired by the Prime Minister ${ }^{47}$.

The Bilateral mixed commission usually discussed legal issues, but some symbolic decisions were made as well - on the eve of the twentieth anniversary of the restoration of Independence, both sides undertook mutual obligations to hold Church services dedicated to the anniversary in dioceses and to emphasise the role

${ }^{43}$ Susitarimas dèl Katalikų Bažnyčios sielovados kardomojo kalinimo ir laisvès atemimo vietose, 23 April 2003, in: Lithuanian Bishops' Conference Archives, digital collection, unnumbered folder "Church-State covenants".

${ }^{44}$ Lietuvos Vyskupu Konferencijos ir Lietuvos Respublikos Sveikatos apsaugos ministerijos susitarimas dèl Kataliku Bažnyčios sielovados teikimo sveikatos priežiūros istaigose, 16 September 2002, No. 3/115, in: Ibid.

${ }^{45}$ Dèl sielovados patarnavimu teikimo sveikatos priežiūros įstaigose, 24 July 2009, No. V-639, in: Register of Legal Acts, https://www.e-tar.lt

${ }^{46}$ Dèl Lietuvos Respublikos Vyriausybès $2001 \mathrm{~m}$. birželio 18 d. nutarimo Nr. 735 'Dèl komisijos, atstovausiančios Lietuvai, sudarymo' pakeitimo, 5 September 2007, No. 921, in: Register of Legal Acts, https://www.e-tar.lt

${ }^{47}$ Dèl Lietuvos Respublikos Vyriausybès 2001 m. birželio 18 d. nutarimo Nr. 735 'Dèl dvišales mišrios komisijos tarptautiniu sutarčiu su Šventuoju Sostu nuostatoms vykdyti dalies, atstovausiančios Lietuvai, sudarymo' pakeitimo, 5 October 2011, No. 1153, in: Ibid. 
of the Catholic Church in Lithuania's way to Independence during the celebrations ${ }^{48}$.

The agreements made an impact on the Church itself - not only by granting it legal protection, but also by transforming the mentality of the clergy. The involvement of religious communities in the network of formalised interactions did not threaten the uniqueness of the Church, but blocked its claims to exceptionality in those cases when its institutions acted in the customary field of social-economic relations rather than the sacral sphere. Gradually the Church began to understand that it was necessary to observe the rules of acting in the environment of the secular State established by bilateral acts. This contributed to the modernisation of Catholics by rejecting clericalism and the persistent feudal habits to manage affairs, e.g., by playing on the respect for the clerical robe shown by officials or employees rather than by legal means. Being international and thus not easily subjected to revisions, the agreements made a positive influence on ensuring the stability of legal acts regulating the most sensitive internal issues.

\section{Concordat versus agreements: experience of integration Church activity into the lithuanian legal system}

In the year 2000 after difficult searches for a consensus in the Church itself and after variable negotiations with Government three agreements between the Holy See and the Republic of Lithuania were signed and ratified. The first one - "Concerning juridical aspects of the relations between the Catholic Church and the State", the second - "Concerning the pastoral care of Catholics serving in the Army", and the third - "On Co-operation in Education and Culture". A Mixed bilateral commission between the State and the Church has been constituted for elaboration and practical implementation of the aforementioned acts. An article analyses a shift from the drafts of concordat to agreements and tensions between Church and

\footnotetext{
${ }^{48}$ Minutes of the session of the Bilateral mixed commission on 14 December 2009, in: Lithuanian Bishops' Conference Archives, digital collection, unnumbered folder "Bilateral mixed commission".
} 
State in spheres of education, culture, social care, pastoral care in the military and hospitals.

SŁOWA KLUCzOwE: konkordat; umowa; Konferencja Episkopatu Liwy; rząd liwtewski; opieka duszpasterska

KEY WORDS: concordat; agreements; Lithuanian Bishops' Conference; Lithuanian Government; pastoral care

\section{ON AUTHOR:}

Prof. Dr. Paulius V. Subačius - full member and vice-president of the Lithuanian Catholic Academy of Sciences, member of the Commission Internationale d'Histoire et d'etudes du Christianisme (Lithuanian section). Author/editor of fifteen books in fields of literature, history, religion, and academic politics. Among them - monograph "Twenty-five Years of Religious Freedom, 1988-2013: Christians in Lithuanian Society after the National Revival" (2016), and critical editions of diaries and letters by bl. bishop Jurgis Matulaitis MIC (Matulewicz). 